\title{
CREATING ACADEMIC ECONOMICS IN BRAZIL: THE FORD FOUNDATION AND THE BEGINNINGS OF ANPEC
}

\author{
Ramón García Fernández* \\ ramon.garcia.fernandez@gmail.com \\ Carlos Eduardo Suprinyak ${ }^{*}$ \\ suprinyak@cedeplar.ufmg.br
}

\begin{abstract}
The 1960s saw the beginning of an effort to improve professional standards in Brazilian academia through cooperation with a few North American institutions, in the context of an important and controversial set of agreements between the Brazilian Ministry of Education (MEC) and the United States Agency for International Development (USAID). In the case of economics, the Ford Foundation was especially relevant, providing substantial funding for the creation of the first graduate programs in the field in Brazil. An important moment in this process took place in 1973 with the creation of ANPEC, an association of graduate programs in economics whose purpose was to organize and stimulate institutional interaction among its members. ANPEC is still today the most important association for academic economics in Brazil, exercising leadership through both its annual meetings and a national unified exam for admission in graduate programs in the field. The paper explores archival material from the period 196474 held at the Ford Foundation, which illuminates both the interaction between representatives of the Foundation and of different Brazilian academic institutions, and the strategy pursued by the former in order to develop the economics profession in the country. We thus seek to contribute to a better understanding of the conflicting motivations that lay behind the creation of ANPEC, and of the effects that the association would have on the emerging graduate programs in Brazil.
\end{abstract}

Key words: ANPEC, Ford Foundation, USAID, FGV, IPE/USP.

Resumo: A década de 1960 testemunhou o início de um esforço de aprimoramento dos padrões profissionais da atividade acadêmica no Brasil por meio da cooperação com instituições norte-americanas, no contexto de um importante (e controverso) conjunto de acordos entre o Ministério da Educação e Cultura (MEC) e a Agência dos Estados Unidos para o Desenvolvimento Internacional (USAID). No caso específico da Economia, a Fundação Ford for particularmente relevante ao prover um volume substancial de recursos para a criação dos primeiros programas de pós-graduação brasileiros na área. Um episódio importante nesse processo ocorreu em 1973 com a criação da ANPEC, uma associação de programas de pós-graduação em Economia cujo propósito era organizar e estimular a interação institucional entre seus membros. A ANPEC é, ainda hoje, a principal associação voltada para a atividade acadêmica em Economia no Brasil, exercendo sua liderança por meio tanto de seus encontros anuais, quanto do exame nacional unificado para admissão em programas de pós-graduação na área. O artigo explora documentação primária do período 1964-74, mantida nos arquivos da Fundação Ford, que ilumina a interação entre representantes da Fundação e de diversas instituições acadêmicas brasileiras, e também a estratégia desenvolvida pela primeira de maneira a desenvolver a profissão de economista no país. Buscamos, assim, contribuir para uma melhor compreensão das motivações conflitantes por trás da criação da ANPEC, e dos efeitos que a associação viria a exercer sobre os nascentes programas de pós-graduação no Brasil.

Palavras-chave: ANPEC, Fundação Ford, USAID, FGV, IPE/USP.

Área ANPEC: 1 - História do Pensamento Econômico e Metodologia

Classificação JEL: B20; A14; A23.

\footnotetext{
- Full professor - Universidade Federal do ABC (UFABC) - Brazil. The author would like to thank CNPq for financial support, and the Ford Foundation (especially Mr. Jonathan Green) for kindly allowing access to its archives.

${ }^{*}$ Associate professor at Cedeplar - Federal University of Minas Gerais (UFMG). The author would like to thank FAPEMIG, CNPq, and Universidade Federal de Minas Gerais for their financial support.
} 


\section{CREATING ACADEMIC ECONOMICS IN BRAZIL: THE FORD FOUNDATION AND THE BEGINNINGS OF ANPEC}

\section{Introduction}

The Brazilian National Association of Centers for Post Graduate Economics (ANPEC) was formally created in 1973, and has since then exerted a leading role in the development of the economics profession in Brazil, particularly in its academic dimension. It has done so mainly using two instruments: the annual meetings sponsored by the association, where recent original works in different fields are presented and discussed by economists from all over the country; and a unified national exam for admission in graduate programs in economics, which is organized by the association and followed by all of its members. Both of these instruments have very clear normative contents. The annual meeting establishes the standards of academic excellence within the country, thus signaling which research avenues are worth pursuing. The national exam, on the other hand, influences the patterns of graduate and undergraduate training in economics adopted in Brazil, defining which subjects and contents students willing to enter graduate school must master (Haddad 1997).

The creation of ANPEC, however, was part of a long process of construction and development of Brazilian centers for graduate training and research in economics - a process in which several actors played important roles. The Ford Foundation was one of these actors, involved as it was in a larger effort to improve the quality of human resources in Latin America, thus helping to promote economic development in the region. The purpose of this paper is to unravel the strategies adopted by the Foundation in her program to develop the economics profession in Brazil, and the extent to which its involvement left lasting marks on the institutional structure of academic economics in the country. In order to accomplish this goal, extensive use will be made of documents relating to the social sciences program implemented by the Foundation in Brazil, currently held in its New York archives.

The paper is divided into five sections, besides this brief introduction and some concluding remarks. Section 2 offers an overview of the early development of the economics profession in Brazil, from the early $20^{\text {th }}$ century to the 1950 s. Section 3 then discusses the efforts to "modernize" Brazilian higher education in general, and economics in particular, which gained strength in the 1960s. Section 4 moves on to an analysis of the Ford Foundation's initial involvement with economics in Brazil, focused on the development of strong national institutions that could provide high-level graduate training and research. Section 5 then pictures the maturing of a new strategy more adequate to the Brazilian reality, involving the creation of a network of complementary national- and regional-level centers. Finally, section 6 shows how ANPEC arose as an outgrowth of previous initiatives that fostered active exchange and collaboration among the members of this institutional network.

\section{Origins and early development of the economics profession in Brazil}

Economics as an academic discipline only had its beginnings in Brazil in the mid-twentieth century, quite a huge delay when compared to countries that had developed a strong tradition in the field already in the $19^{\text {th }}$ century. This was not, however, a problem exclusive to economics - the first Brazilian universities were only created during the first half of the past century. It is interesting to notice, in this respect, the difference between Brazil and other Latin American countries. Local universities had been created in most of the Spanish-speaking countries well before their independence. The Portuguese crown, however, did not institute any universities in Brazil, and only in the first half of the $19^{\text {th }}$ century a few scattered colleges - specializing on Medicine, Law and Engineering - were created. These attempts did not include, however, any concern with the development of specialized studies in economics - something rather comprehensible, given that most universities in more advanced countries only created such courses much later ${ }^{1}$.

\footnotetext{
${ }^{1}$ Our account of the origins of Brazilian universities is strongly based on Favero (2006).
} 
The economic affairs of the country were carried on by practical men experienced in commerce, as landowners, or even in the army. Most of them had studied in Portugal, Coimbra being the intellectual lighthouse for Brazilian elites during the whole Imperial period, and even after the proclamation of the Republic in 1889. The first decentralized efforts by local elites to create universities in Brazil only took place at the beginning of the $20^{\text {th }}$ century; after some failed initial attempts, the first Brazilian university, Universidade do Rio de Janeiro ${ }^{2}$, was finally opened in $1920^{3}$. Meanwhile, a few high-school courses in business and accounting had been created, thus generating some pressure for the establishment of short (three-year) college degrees on similar subjects, which would only begin to function in the 1930s. The prestige conferred by such degrees was much smaller than that attached to the traditional ones - Law, Medicine and Engineering - whose students came from non-technical high-school programs. Consequently, there was added pressure for the establishment of properly academic courses in economics, coming in particular from the associations founded in Rio de Janeiro and São Paulo by holders of those minor degrees ${ }^{4}$.

Two steps were given in order to establish college programs in economics that could garner academic respect. The first one was the creation of a private faculty, the Faculdade de Ciências Econômicas $e$ Administrativas do Rio de Janeiro (FCEARJ) in 1938. The second one involved setting up programs in economics within the two leading universities of the time. The Universidade Federal do Rio de Janeiro (UFRJ) thus officially began to offer undergraduate training in economics in $1945^{5}$; a year later, the Universidade de São Paulo (USP) would follow suit.

These measures, however, did not fulfill the expectations of Brazilian economists. In the strongly regulated Brazilian labor market, people in any liberal activity sought measures to restrict entry, a goal usually attained through the regulation of professions. The first economists in Rio de Janeiro had already formed a professional association, the "Order of Economists", in the early 1930s, but they began striving to obtain formal regulation soon thereafter. In 1951, the Federal Law 1411 was passed, creating the Federal Council of Economists (COFECON) and its regional representations, the CORECONs; from then on, only people formally registered at their local CORECON would be allowed to work in activities defined as the exclusive competence of economists (Castro 2001, p. 41).

Despite these improvements, the economics profession in Brazil still presented many obvious problems. Since no formal studies in the field had previously existed in the country, and given the sparse contact with universities abroad, most of the professors who taught at the recently created college programs were either lawyers or accountants, working only part-time at the universities and equipped with dubious knowledge of economic theory. Some of these self-educated economists, of course, are regarded today as founding fathers of the economics profession in Brazil, Eugenio Gudin (1886-1986) perhaps being the paradigmatic such example. Nevertheless, there is currently a widely held conviction that the academic standards of the period were rather low. One important difference that stood out in the comparison with U.S. curricula at the time was the absolute lack of any graduate training. One could submit a supervised thesis and become a "Doctor in Economics" without taking any further courses after graduation.

It would be unfair to say that there was an absolute lack of relevant and quality work in economics being done in Brazil at the time; most of it, however, took place outside of the academic environment. Both in the government and in the private sector, there were many self-educated people who had a practical knowledge of economic affairs. There were also a few influential Marxist theorists with the requisite background in (Marxian) economics. These pioneers include the engineer and businessman Roberto Simonsen (1889-1948), who was the main early-20 ${ }^{\text {th }}$ century advocate of industrialization in Brazil; Celso Furtado (1920-2004), a lawyer who obtained a Ph.D. in economics at the Sorbonne shortly after the war,

\footnotetext{
${ }^{2}$ The university was called Universidade do Rio de Janeiro until 1937, when it was restructured and renamed Universidade do Brasil. In 1965, it was once again renamed, this time to Universidade Federal do Rio de Janeiro (UFRJ), a denomination it retains until today.

${ }^{3}$ Local elites created a university in Curitiba in 1912. The federal government did not recognize it, and forced its dissolution into a few faculties. The federal university later created in the same city (Universidade Federal do Paraná) considers itself as the continuation of the original university, and so claims the title of first Brazilian university.

${ }^{4}$ This process is well described in Castro (2001).

${ }^{5}$ Actually, the new course just incorporated the FCEARJ - after a short transition, all its professors became public employees.
} 
and became one of the leading figures of the so-called Latin American structuralist school of economics that gravitated around $\mathrm{CEPAL}^{6}$; and the Marxist lawyer and historian Caio Prado Junior (1907-1990), who wrote some of the most influential early works on the economic history of Brazil.

In terms of institutions, it would be difficult to exaggerate the importance of the role played by the Fundação Getulio Vargas (FGV), a think tank created in 1944 to support the modernization of Brazilian public administration, and which had the above-mentioned Gudin as one of its leading figures. The Foundation, whose original purpose was to train high-level public employees, soon took the lead in designing the Brazilian system of national accounts, in particular after the creation, within its structure, of the Brazilian Institute of Economics (IBRE) in 1951. The Vargas Foundation was also responsible for launching the first Brazilian academic journal of economics - Revista Brasileira de Economia - in 1947.

Improvements in the academic standards of Brazilian economics were already visible during the 1950s. The Vargas Foundation, in particular, had established connections with international organizations and foreign universities, and leading economists such as Gottfried Haberler, Nicholas Kaldor, Gunnar Myrdal, Ragnar Nurkse, Raúl Prebisch, and Jacob Viner visited the institution during those years. People who held part-time positions at UFRJ were hired by FGV, thus strengthening the links between Brazilian academy and the leading independent think tank of the time (Loureiro 1997c). Within public administration, the creation in 1953 of the National Bank for Economic Development (BNDE) made it possible to assemble a highly qualified technical team, hired through rigorous admission exams. Similar qualified groups were also created in other government sectors, especially during Juscelino Kubitschek's presidential term (1956-61).

According to Bielschowsky (1988), there were three main currents of economic thought in Brazil during the 1940s and 1950s, which he characterizes as "liberal" (in the economic, pro-market sense), "developmentalist" and "socialist". The "developmentalist" current can be further divided into three subgroups: one located in the private sector, a second one based in the public sector but advocating a leading developmental role for the private sector, and a third one, also situated in the public sector but adopting a firm pro-state stance. This pluralist picture bears relation to the democratic period experienced in Brazil from 1945 to 1964, during which vivid discussions about socioeconomic issues were held among both intellectuals and the public in general ${ }^{7}$. Regardless of their perspectives and ideological inclinations, however, it is worth noting that none of these schools of thought were primarily based at universities - in stark contrast with the situation that would prevail in Brazil a few decades later.

\section{Modernizing Brazilian economics}

Different indications suggest that, by the beginning of the 1960s, there was a rather widespread belief among Brazilian economists that something should be done in order to improve professional standards, and that this required strengthening connections with foreign institutions. Among the "developmentalists", for instance, many people went to Santiago to take courses at the CEPAL school, while the latter also started offering short-term courses in Rio. The Vargas Foundation, on the other hand, opened a new school in 1960 - the Center for the Improvement of Economists (CAE) - whose free courses were perceived as a natural path towards getting accepted to a (top) graduate program in the U.S. (Bacha 1996). It is worth remembering that the FGV was only a research institution at the time; no undergraduate training was offered ${ }^{8}$, although many of its researchers taught part-time at the UFRJ, while some also held jobs in the public sector (Tavares 1996).

\footnotetext{
${ }^{6}$ In English, ECLA, the United Nations Economic Commission for Latin America. In 1984 the name was changed to add "and the Caribbean", resulting in the current acronym ECLAC.

${ }^{7}$ The only party formally excluded from the democratic arena was the Communist Party (PCB), which had been declared illegal in 1947. In spite of this prohibition, the PCB proper, and Marxist intellectuals as a whole, continued to play an important role at least until the 1964 military coup.

${ }^{8}$ Curiously enough, the FGV opened a second branch in São Paulo around that time. A division of labour was established according to which the São Paulo branch would become a business school, leaving economic research firmly centered in Rio. An undergraduate program in business began in São Paulo in the mid-1950s, assuming a leading national position in the field. The Rio branch, on the other hand, would only create an undergraduate program in economics in 2001.
} 
All along this period, different U.S. organizations, both public and private, had assisted in the development of Brazilian research institutions. Connections with the Ford and Rockefeller foundations were very important for economics, while the USDA played a crucial role in the creation of a center for agricultural studies at the FGV. These and other similar initiatives took place within the context of the Cold War, the creation of the Alliance for Progress, and the increasing polarization in Brazilian politics that ultimately led to the military coup of 1964. An important source of changes in the Brazilian educational system at the time were the MEC-USAID agreements, which sought to promote structural reforms on all levels of education with technical and financial assistance from the United States government ${ }^{9}$. The rationale behind these agreements involved the introduction of a bias towards more technical and applied training in Brazil, with the purpose of improving the qualification of the domestic labor force and thus fostering economic development.

In economics, the interaction between North American and Brazilian institutions developed simultaneously on two fronts. Within the government, the Bureau of Applied Economic Research (IPEA) was created ${ }^{10}$ as a think tank in charge of elaborating long-term economic policy. At the universities and research centers, on the other hand, there slowly developed an effort to establish higher academic standards for training in economics. On the Brazilian side, two groups of economists were at the forefront of this effort, one at IBRE, in Rio de Janeiro, and the other in São Paulo, led by Antonio Delfim Netto, head of the Faculty of Economics at USP. On the American side, Werner Baer, a specialist in the Brazilian economy who had recently moved from Yale to Vanderbilt, was hired by USAID to help develop the first graduate programs in economics in Brazil at the MA level ${ }^{11}$. This was a rather expensive bet: American professors were expected to spend time in Brazil, while Brazilian students would pursue high-level graduate training in the US (many, though not all, at Vanderbilt). It was within this context that long-term support by the Ford Foundation for economics in Brazil was first negotiated (Baer 1997).

Another important landmark in the development of graduate training in economics in Brazil was a meeting held in 1966 in Itaipava, a favorite holiday retreat for the wealthy in the hilly area outside of Rio de Janeiro. The meeting gathered several prominent economists from different institutions (all from the Rio-São Paulo axis) in order to discuss the current state of economics education in the country. A consensus clearly emerged among all participants, who uniformly qualified the level of undergraduate training as very weak ("too much in quantity and too little in quality"). Most of the programs offered an excessive number of classes on subjects such as law and accounting, which thus made them much closer in spirit to business schools, rather than centers for academic economics (Loureiro 1997b).

One of the most important conclusions arrived at in the Itaipava seminar was the need to create something similar to the American Economic Association in Brazil, in order to raise the academic standards of the profession. However, the possibility that such an association could be seen as a competitor to the legally based Council (COFECON) led to a different move: rather than offering membership to individual economists, the new association would gather institutions that were engaged in graduate training in economics (Baer 1997). This decision would culminate in the creation, in 1973, of the National Association of Centers for Post Graduate Economics (ANPEC).

Concern with the creation of graduate programs was not, however, exclusive to economists other professions were at the very same crossroads. Graduate level studies had existed, somehow chaotically, since the creation of the first Brazilian universities; in 1931, moreover, a decree was issued establishing that the latter should have research-related activities as one of their goals, which led to some development in academic research along the following three decades ${ }^{12}$. Given the very different structure,

\footnotetext{
${ }^{9}$ Alves (1968) and Arapiraca (1979) offer critical analyses of these agreements.

${ }^{10}$ The name "Bureau of Applied Economic Research" was only adopted in 1967, after a change in the institute's legal status.

${ }^{11}$ Nicholas Georgescu-Roegen, one of the most important Vanderbilt economists at the time, was also closely involved in these efforts, visiting Brazil several times during this period.

${ }^{12}$ It is worth noting that the two main government institutions that, until today, offer financial support for academic research in Brazil - the National Research Council (CNPq) and the Commission for Improvement of Higher Education Personnel (CAPES) - were created in the early 1950s, well before the regulation of graduate-level training. Besides its role in academic funding, CAPES is also the agency that controls graduate studies in Brazil - degrees issued by programs not authorized by CAPES are
} 
purposes, and requirements adopted by the several graduate programs that existed at the time, the Federal Council of Education issued a norm in 1965 (Parecer CFE 977/65) establishing criteria to guide the development of graduate education in Brazil. The norm created a distinction between two kinds of graduate studies. The so-called post-graduate programs involved advanced training and research, both at the Master's and Doctoral levels; on the other hand, the several extension or "specializing" programs offered complementary professional training for people who already held a university degree ${ }^{13}$. Regarding the former, the norm established that the presentation of a thesis or dissertation could not be a sufficient requirement for obtaining a degree - a minimum amount of course load was also mandatory (Cury 2005).

In the wake of these institutional changes, the University of São Paulo inaugurated in 1966 the first Master's program in economics in Brazil. The following year, the FGV would remodel its informal CAE into a formal Master's program, thus creating the School of Post-Graduate Economics (EPGE) (Tavares 1996). At the same time, other institutions beyond the Rio-São Paulo axis decided to join the movement, trying to benefit from connections with foreign institutions in order to improve their programs in economics. Research in economics thus began gradually to move into the universities, a significant departure from the reality that had prevailed in the country so far. This newly created academic environment soon intensified institutional interaction and mobility: professors started moving across universities and establishing collaborative networks, a stream of foreign visiting researchers brought different perspectives to bear upon the Brazilian reality, and an increasing number of young Brazilian economists went abroad for advanced graduate training ${ }^{14}$. ANPEC was formally created in 1973 with the purpose of coordinating part of these initiatives, and thus providing a common reference point for all its members. As such, it bore the marks of the process that had led to the emergence of the new Brazilian centers for graduate training and research in economics - a process in which the Ford Foundation played a prominent role.

\section{Building institutions in Brazil}

The Ford Foundation's efforts to develop graduate training and research in economics in Brazil began in the early 1960s, as part of a general developmental strategy for Latin America and the Caribbean that stressed improvements in the quality of human resources and the production of reliable inputs for public policy. Initial grants were made, on an experimental basis, to a few selected academic institutions, but throughout the decade, the Foundation's commitments in the area grew substantially in size, structure, and diversity, eventually turning into a full-fledged program for the social sciences in Brazil. These initiatives fell under the general responsibility of the Office for Latin America and the Caribbean (OLAC) in New York, while being managed on-site by the Foundation's office in Rio de Janeiro, established in 1961 under the supervision of Reynold Carlson, a Vanderbilt development economist and Harvard Ph.D. who specialized in Latin American studies.

Support for the social sciences in general, and for economics in particular, followed the general lines of the Foundation's so-called "institution-building" approach. In other areas of the world such as Africa and the Middle East, efforts were geared mostly towards cooperation with governmental agencies in charge of planning and developmental policies. The strategy devised for Latin America, however, was different: faced with countries that already had an intricate and long-established governmental apparatus, the Foundation chose to channel its support into institutions that could produce specialized knowledge outside of the confines of state bureaucracies (Miceli 1993, pp. 255-6). The overall stated purpose was to help create and/or consolidate a few high-level institutions for graduate training and research that would subsequently fulfill a "seeding" role - supplying well-trained economists for other academic institutions, government agencies, and the private sector, while at the same time leading the way in advanced research

\footnotetext{
not valid in the country, and degrees obtained abroad must be submitted to one of the universities authorized by CAPES to certify them.

${ }^{13}$ These programs would be later known, respectively, as stricto sensu and lato sensu graduate programs (in Latin, strict meaning and wide meaning) - expressions that were not used in the original norm.

${ }^{14}$ On the experiences of the Brazilian students as seen from the perspectives of their professors in the U.S., see Goodwin \& Nacht (1984).
} 
specifically geared towards addressing the developmental problems of the recipient nation.

With substantial support from the Ford Foundation and other sources such as USAID, it was expected that these carefully chosen institutions would exert a trickle-down effect over the whole economics profession in the area under consideration. This general strategy, however, very quickly came into conflict with Brazilian reality. As Werner Baer, OLAC's program advisor in economics, would later state in a background report, the initial grants in economics in Brazil ${ }^{15}$ produced dismal results because "the archaic nature of the host institutions made effective use of the funds difficult" . The archaism, from the Foundation's perspective, rested mainly on the faculty structure of Brazilian universities, dominated by "catedráticos"17 whose strong vested positions gave them enormous institutional power and influence, usually not accompanied by equivalent academic credentials. This state of things, it was felt, "made reform almost impossible"18.

The solution found was to create new institutional spaces, within the universities, where it would be possible to develop a new, "modern" kind of training and research. The purpose of the new "centers" of graduate studies and research was to strike a balance between institutional flexibility, on one hand, and fruitful interaction with university life in general, on the other. Regarding the latter, a particularly important goal was to promote gradual changes in the course of undergraduate training, both through the direct influence of highly qualified professors over their students, and the indirect demonstration effects of the requirements for success in advanced graduate training. The new centers were thus conceived as "semiautonomous appendices to faculties"19 - halfway between genuine think tanks and more traditional university departments.

In order to pursue its institution-building goals, the Foundation made use of a variety of instruments and tactics. The budgets of grant proposals approved during the period usually contained some or all of the following items: fellowships for graduate students at the recipient center; salary supplements for staff members ${ }^{20}$; support for visiting professors; fellowships for Brazilian graduate students in North American universities; library acquisitions and general administrative expenses. The main lines of action, though, clearly revolved around two axes: high-level graduate training in North American universities, and absorption of returning MAs, ABDs and Ph.Ds. within the Brazilian centers. This is clear from the evaluative reports presented by FF staff, which usually put a great emphasis on "staff development" - a concept that, in this context, invariably meant graduate training in the United States. The hopes deposited on the graduates sent for study abroad obviously involved the potential influence they could have, upon their return, on the quality level of training and research in Brazil, but much more was at stake. Given the institutional structure in which Brazilian academia was immersed, the return of economists who had experienced the environment of a top-level graduate program abroad also brought with it the promise of increased pressure for change and reform - a drive for "modernization" patterned after the North American model $^{21}$.

\footnotetext{
${ }^{15}$ The three original grantees were the Getúlio Vargas Foundation and the Federal Universities of Ceará and Rio Grande do Sul.

${ }^{16}$ Baer (1974).

${ }^{17}$ The term "catedrático" referred to professors who held "cátedras", or "chairs". In the Brazilian university system of the time, the position stood at the top of the academic hierarchy and conferred upon its holder very large powers institutional powers, including the right to influence educational standards and hiring practices.

18 Baer (1974).

${ }^{19}$ Baer (1974).

${ }^{20}$ The payment of salary supplements with FF resources was a controversial issue. Initially, this kind of support was predicated on the inflexible budgets of Brazilian universities, which could not compete with the private and government sectors in the market for highly trained economists. As institutional reforms gradually raised the average wages paid by the universities, salary supplements became a way of supporting graduates who had just returned from abroad while their morose hiring process was not yet completed.

${ }^{21}$ One of the clearest examples of this kind of "institutional" expectations can be found in a memorandum written by Werner Baer on January 6, 1970. In the document, Baer discusses some recent problems with the staff at IPE/USP, arguing that Miguel Colasuonno, then director of the Institute, had "institutionally loyal friends" who were "rather weak intellectually", whereas the "intellectually strong people were opportunists" who tried to "undermine the institution" and "use it when it suits their purpose". In Baer's perspective, a solution for that problem could already be foreseen: "Once the first crop of Ph.D. returns, Miguel will have a core on which to build" (Baer 1970).
} 
The two institutions originally chosen to spearhead the development of the economics profession in Brazil were the University of São Paulo and the Getúlio Vargas Foundation. The course of action followed in the case of USP was a clear example of the new strategy devised for this second wave of involvement with Brazilian economics by the Ford Foundation. A new Institute for Economic Research (IPE) was created, in 1964, as an "independent entity" within the university's Faculty of Economic and Administrative Sciences ${ }^{22}$. IPE's purported mission was to become a "first class graduate center of economics where teaching and research will be combined into a single operation", and to "develop a cadre of well trained individuals to furnish the teaching staff for other universities, multiplying the innovation function, while others will be rapidly absorbed by the demand of government and private enterprise" 23 . In order to further development of the new center, IPE was the object of a specific USAID-Vanderbilt contract under which, starting in 1966, several visiting professors came to Brazil to teach graduate courses and engage in collaborative research activities. Some of the Vanderbilt economists who participated in this exchange program were Nicholas Georgescu-Roegen, William Nicholls, William Thweatt, and Andrea Maneschi. Besides providing assistance by foreign visiting professors, the AID-Vanderbilt contract also created opportunities for IPE's staff and graduates to pursue advanced studies in North American universities.

The conditions at the Getúlio Vargas Foundation, on the other hand, were quite different. As a private foundation with substantial access to public funding, the FGV already had a more flexible institutional structure on which to build. Moreover, the institution-building effort would not have to start from scratch, since the Foundation already offered a one-year non-degree graduate program in economics (the first of its kind in Brazil), and also had a solidly established reputation as a research center in economics. The latter was due to the activities of IBRE, which specialized in applied research on policyoriented topics - in particular the collection of economic data and the publication of regular economic indicators. The Ford Foundation saw the FGV's hybrid institutional nature as a virtue, resulting in a "longestablished tradition of independence from either government or private sector control of its research and training programs" 24 . The Vargas Foundation had also received one of the original FF grants to Brazil in 1960, and by the time a second grant was being discussed, around 1967, it already offered a two-year master's level program at the EPGE, led by the prominent Brazilian economist Mário Henrique Simonsen. Given this state of affairs, the new grant was geared mainly towards supporting two large research projects that would be developed by IBRE - one exploring "Brazilian manpower problems", and the other focusing on the sources of growth in the Brazilian economy ${ }^{25}$.

Two very distinct situations thus confronted the Ford Foundation in its attempt to develop highlevel centers of academic economics in Brazil. With respect to IPE, all sorts of institutional barriers had to be overcome. Delfim Netto, the leading Brazilian economist behind the creation of the Institute, had since left to become the Brazilian Minister of Finance, thus temporarily leaving IPE without effective leadership. After returning from a recent stint in São Paulo, Georgescu-Roegen reported that everything from gasoline to bilingual secretarial help was missing ${ }^{26}$. The Vargas Foundation, on the other hand, was widely regarded as the most prominent and accomplished Brazilian center for training and research in economics. Its second grant proposal to the Ford Foundation received strong backing by such imminent (and diverse) economists as Chicago's Arnold Harberger and Harvard's Albert Hirschman ${ }^{27}$. The same Georgescu-Roegen thus expressed, in early 1967, his impressions about the two programs:

During my visit for some lectures at the Vargas Foundation last summer, I had occasion to convince myself of how well their graduate program is progressing under the direction of Mario Simonsen. I even wrote to Rey Carlson my disappointment to see the São Paulo program, by comparison, lagging so far behind ${ }^{28}$

\footnotetext{
${ }^{22}$ The creation of IPE was the result of a joint agreement among USP, the Ford Foundation, and USAID.

${ }^{23}$ Baer (1974).

${ }^{24}$ Widdicombe (1967).

${ }^{25}$ Widdicombe (1967).

${ }^{26}$ Widdicombe (1966).

${ }^{27}$ Widdicombe (1967).

${ }^{28}$ Georgescu-Roegen (1967).
} 
Indeed, it was a common argument among FF staff at the time that a closer cooperation with IBRE would be of great help for the satisfactory development of IPE. Accordingly, the two centers established in 1967 a program for joint recruitment of graduate students, and Isaac Kerstenetzky - one of IBRE's research directors - was invited to serve as a permanent research consultant to IPE. Reporting on a recent agreement for a joint research project, Baer stated: "I hope this will be the beginning of many such cooperative efforts" 29 .

\section{Regional Outreach and Institutional Networks}

Towards the end of the decade, however, a new strategy for the development of Brazilian economics was beginning to take shape among FF staff, in particular due to the first-hand knowledge of Brazilian conditions already acquired, at that time, by the Rio office. Although the standard institutionbuilding approach called for the nurturing of one or two high-level academic centers of national scope, it was gradually felt that the specificities of Brazilian society made necessary the adoption of a more regionalized alternative. The Foundation's representatives in Brazil constantly repeated the rationale behind this new strategy, almost like a mantra: in a country of the size and diversity of Brazil, and with such regional disparities in socioeconomic development, it was necessary to support a few smaller regional centers that could help addressing local problems. Brazil's Northeast, in particular, deserved a differential treatment that catered to its chronic and severe developmental challenges ${ }^{30}$. A memorandum written by William Carmichael, head of the Rio office from 1968 to 1971, indicates the extent to which this argument had, by the early 1970s, turned into a standard defense for a regional strategy to Brazil:

As stated ad nauseam I'm afraid, Brazil is a very large country with pressing human resources and research requirements in each of its several important regions. The situation is further compounded by problems of internal brain drain, which generate serious doubts about relying on a geographical "trickle outward" approach. Specifically, we believe that the pressing developmental needs of the 30,000,000 Northeasterns make it strongly desirable that we include institutions in that region in the network of Foundation-supported activities in such fields as agricultural economics and economics [emphasis in the original] ${ }^{31}$

In fact, there were precedents for the direct involvement of the Ford Foundation in the Brazilian Northeast. The Federal University of Ceará, one of the region's most solid academic institutions, had been one of the original FF grantees in the early 1960s. In 1964, an agreement was signed between the university, USAID, the Ford Foundation, and SUDENE - a Brazilian governmental agency created in 1959 with the specific purpose of fostering the development of the Northeast - which led to the creation of the Center for the Improvement of Economists in the Northeast (CAEN). Reports supporting this grant stated that, in Northeast Brazil, "manpower skills are scarce in all forms, but conspicuously absent is a cadre of professionally trained people to undertake studies and provide actionable programs in economic development" 32 . The main purpose of the new center would thus be to "provide some postgraduate training which is geared to the lower starting level of the Northeast universities, for graduates expected to remain in the Northeast to staff the various regional and state agencies"33.

The underlying reasoning was twofold. On one hand, Northeastern economists desperately needed graduate training - the level of their undergraduate studies was simply too low to capacitate them to properly tackle the intricate developmental problems of the region. On the other hand, however, they should not be overtrained, in order to avoid internal brain drain towards more developed areas and thus guarantee an adequate supply of qualified economists to local universities and governmental agencies. In other words, the area required graduate training and research initiatives of a different nature than those provided by high-level centers such as IPE and FGV. Foundation staff in Brazil accordingly started to plea for a change in strategy, but their campaign initially met with considerable resistance from New York.

\footnotetext{
${ }^{29}$ Baer (1968).

${ }^{30}$ See, for instance, Bell (1969a), Bell (1969b), and Carmichael (1969).

${ }^{31}$ Carmichael (1970).

${ }^{32}$ Unidentified author (1964).

${ }^{33}$ Unidentified author (1964).
} 
Throughout 1969, there were negotiations surrounding a possible FF grant to support the creation of a joint graduate program in economics and sociology at the Federal University of Pernambuco - what would later become the Integrated Master's Program in Economics and Sociology (PIMES). In a memorandum from September 16, 1969, Carmichael told Harry Wilhelm, from the New York office: "My colleagues and I were disappointed to learn of your initial reaction to our proposed grant" 34 . A few days earlier, Wilhelm had communicated him that "the proposed grant to Pernambuco would take us in the opposite direction from the one we want to travel" 35 , a position that was based on reservations recently expressed by some of the Foundation's staff and consultants. Nita Manitzas, OLAC's Program Officer, recognized that, given the peculiar nature of the Brazilian case, "the spread of our institutional involvements must be judged accordingly"; in the case of Pernambuco, however, she wondered "whether the issue is one of spread or simple scatteration"36. Kalman Silvert, the NYU Latin Americanist who served as general consultant for the FF's social sciences program, argued that "one can persuasively state that this grant is not justified in terms of alternative ways of spending monies" 37 . Wilhelm subsequently picked up these arguments: "I wonder whether the same monies invested in moving toward a doctoral program elsewhere in Brazil [...] would likely yield greater dividends"38.

The Rio personnel, however, were already committed to the new stance. On his reply to Wilhelm, Carmichael discussed at some length what he termed the "concentration-diffusion issue":

This, of course, is a familiar issue, especially for those of us who are working in Brazil. Whether the field is agricultural economics, or (general) economics, or sociology, we find ourselves returning to the question of whether we should channel our investment exclusively into one or possibly two strong national centers in central Brazil, or whether modest portions of the total sum applied would better be allocated directly to institutions serving the needs of important regions of Brazil ${ }^{39}$

Carmichael's answer to this question was emphatic: "I remain more convinced than ever that we need interlocking national and regional programs" ${ }^{40}$. Accordingly, his position eventually triumphed. On a memorandum addressed to Wilhelm shortly thereafter, Silvert noted: "Bill [Carmichael] is making an issue of the case, and the grant is not of sufficient size or so patently one thing or another as to warrant our going to the wall with the Brazil office" ${ }^{41}$. The grant proposal was revised and finally approved, although doubts still lingered. Silvert warned that Carmichael "does not tell us when a sufficiency of 'regionalization' of a program has occurred, merely that we have spread grants geographically before, and should do so again" 42 . A few months later, when approval was imminent, he still asked for a grant proposal that "does not relate this humble undertaking to the entire problem of poverty and underdevelopment in the Northeast" 43 , clearly indicating the general political connotation that had been attached to the argument for regional outreach by the Foundation's staff in Brazil.

The subsequent expansion and spread of FF support to academic economics in Brazil bears testimony to the success of the strategy pursued by the Rio office. By the early 1970s, the Foundation had offered grants to five centers other than IPE and IBRE: besides CAEN and PIMES, other beneficiaries included the University of Brasília, the Center for Regional Development and Planning (CEDEPLAR) at the Federal University of Minas Gerais, and the Center for Advanced Amazonian Studies (NAEA) at the Federal University of Pará ${ }^{44}$. However, this regionalized approach depended crucially on a second

\footnotetext{
${ }^{34}$ Carmichael (1969).

${ }^{35}$ Wilhelm (1969).

${ }^{36}$ Manitzas (1969).

${ }^{37}$ Silvert (1969a).

${ }^{38}$ Wilhelm (1969).

${ }^{39}$ Carmichael (1969)

${ }^{40}$ Carmichael (1969).

${ }^{41}$ Silvert (1969b).

${ }^{42}$ Silvert (1969b).

${ }^{43}$ Silvert (1969c).

${ }^{44}$ There was also, at the time, an active grant in agricultural economics to the Institute of Economic Studies and Research (IEPE), at the Federal University of Rio Grande do Sul. According to a report written by Werner Baer in 1974, the Institute "now has a
} 
component for its success: the establishment of an effective institutional network connecting the grantees, through which the high-level national centers could help foster the development of their smaller, regional counterparts, while also making it possible to capitalize on the potential gains arising from specialization and complementarities in research.

As already mentioned above, by the late 1960s, representatives of the Foundation were already actively stimulating cooperation between IPE and IBRE as a way of leveling the perceived imbalance between the two leading programs in economics. In 1968, a new round of negotiations around the CAEN grant formally established, among other things, that IPE would provide visiting professors to the Northeastern center under the AID/Vanderbilt agreement, and that CAEN's best students would be eligible for finishing their graduate studies at $\mathrm{EPGE}^{45}$. The joint recruitment of students established between IPE and EPGE was partially extended to CAEN in 1969, and Baer reported that the center expected to receive, later that year, a visiting professor with "wide experience in project analysis", either from the Vargas Foundation or from CEDEPLAR ${ }^{46}$. This grand vision of an integrated network of collaborative and complementary centers for graduate training and research in economics was explicitly brought forward by Peter Bell, who served temporarily as head of the Rio office between 1967-68, in his original memorandum supporting the PIMES grant:

[...] we believe that modest support for regional institutions like CEDEPLAR at Minas Gerais and the program at Pernambuco can importantly strengthen the national network of social scientists. Such institutions can complement, question, and inform at the regional or local level the theories and policies conceived for the nation; they can also in turn draw on the national institutions for staff training, visiting lecturers, and research consultants ${ }^{47}$

However, at the same time as the Foundation tried to consolidate an institutional network connecting its growing number of grantees in Brazil, changes were quickly taking place within the two leading centers. Reports on IPE became increasingly positive and optimistic as the decade approached its end. Early in 1968, Baer stated that, despite some lingering problems, IPE had recently made "much better progress than any of us had hoped"48. The background report for a supplemental grant in 1969 thus presented IPE's case: "During the period of the initial grant IPE developed a strong graduate training program, completed several research projects of good quality, and became the key institution in a network of economic research and training centers in Brazil"49. The latter point was a reference to a fledgling new initiative that the Foundation, in particular, regarded as crucially important: the so-called IPE extension program. A more detailed description of the program was given a few paragraphs below:

Largely through the efforts of IPE's staff, a national network of economics training and research centers has been developed in Brazil. Besides providing advanced training for professors from regional centers, IPE has initiated an extension program under which its staff and that of IBRE teach short-term intensive courses and lend assistance to the research activities at regional economic centers such as the Center for the Improvement of Economists in the Northeast in Ceará, CEDEPLAR in Minas Gerais, and the Institute of Human Sciences in Pernambuco - all present or prospective Foundation grantees. IPE also finances and coordinates professional staff interchanges among the regional centers ${ }^{50}$

The extension program accordingly became a specific item of financial support in subsequent FF grants, and the successful enlargement of IPE's regional outreach and influence went hand-in-hand with the strengthening of its role as the Ford Foundation's main instrument for implementing its policy for Brazilian economics. Already in 1974, Baer could state:

\footnotetext{
substantial non-agricultural economics portion", which brought it in close connection to the other grantees in "general" economics (Baer 1974).

${ }^{45}$ Bell (1968); Braga et al. (1968).

${ }^{46}$ Baer (1969a).

${ }^{47}$ Bell (1969a)

48 Baer (1968).

${ }^{49}$ Bell (1969c).

${ }^{50}$ Bell (1969c).
} 
IPE's successful growth has greatly contributed towards fulfillment of the Foundation's objectives in helping to develop the Brazilian economics profession. IPE has come through as the "king-pin" in the effort to build a system of institutions with a self-generating capacity in high-level economics training and research ${ }^{51}$

Meanwhile, developments at the Vargas Foundation were far from encouraging. Whereas in 1967 Baer could speak of the FGV's "unassailable position within Brazil as a research and teaching institution of the highest intellectual caliber and integrity" "52, his assessment two years later was that "new financial support for the Fundação Getúlio Vargas should only be made after a thorough institutional evaluation and possible agreement on changes in the institutional structure" ${ }^{\text {. }}$. In November 1970, Carmichael pondered: "Unfortunately, the development of [IBRE] has been impaired by a host of leadership and administrative problems" ${ }^{\prime 5}$. The problems alluded to included the over-centralized decision-making structure of the Vargas Foundation; an excessive focus on "collective" research projects at IBRE, with little room for personal initiative and a resulting lack of in-depth analysis; and deteriorating conflicts of leadership between IBRE's research directors - Isaac Kerstenetzky, Julian Chacel, and Anibal Villela.

The so-called "Manpower Project" had been divided in two sub-sections: one dealing with the industrial-services sector, under the guidance of Kerstenetzky, and the other dealing with the agricultural sector, led by Chacel. After noting, in a memorandum from August 1969, that the project should be "much further along than it is today", Baer stated: "Part of the difficulty is due to the organizational structure of IBRE and due to jurisdictional disputes between Kerstenetzky and Chacel"55. After Kerstenetzky left IBRE, in 1970, to become president of the Brazilian Institute of Geography and Statistics, Chacel took over the entire project, but his performance was the subject of harsh criticism by the Ford Foundation's Brazilian staff. Commenting on a narrative report submitted by IBRE in 1973, Baer told Nicholson that "the 2 1/2 pages reporting on the manpower study, which was supposed to be the major project, makes pathetic reading". The document contained only descriptions of problems encountered during the project's execution, but Baer found "none of the stated reasons for the delay to be convincing" 56.

The "History Project" 57 , on the other hand, had been developed quite satisfactorily by Villela, who had since left IBRE to work at IPEA. Baer believed that the resulting work, "Sources of Brazilian Economic Growth, 1889-1945", would become a "standard reference work" on the economic history of Brazil $^{58}$. However, personality conflicts between Chacel and Villela also prevented this project from becoming a triumph for IBRE's research program. Due to the Vargas Foundation's sluggishness in publishing the results, and IBRE's willingness to present them as an anonymous research report, Villela decided to take the matter into his own hands and publish the work through IPEA. He was chastised for that by both Chacel and Luiz Simões Lopes, the Vargas Foundation's president at the time ${ }^{59}$; to Baer, however, his decision was perfectly reasonable given the circumstances ${ }^{60}$.

In stark contrast with the situation that prevailed a few years earlier, Baer thus concluded his comments on IBRE's final narrative report:

I am afraid that this grant to the Vargas Foundation's IBRE was one of the most ineffective ones we have made in Brazil. The one bright spot - the economics history project - is dismissed due to personal problems. To stop the agony, I suggest we accept this unsatisfactory report as the necessary narrative report for grant closing purposes. I

\footnotetext{
51 Baer (1974).

${ }^{52}$ Baer (1967). In the same document, Baer stated: "In my travels around the country and in my current activities at the University of São Paulo, I am always struck by IBRE's tremendous prestige and by the way everyone always looks to IBRE for intellectual leadership in economics". He then concluded: "I would even go so far as to say that its standing within Brazil is similar to Harvard's standing within the U.S.".

${ }^{53}$ Baer (1969b).

${ }^{54}$ Carmichael (1970).

55 Baer (1969b).

56 Baer (1973b).

${ }^{57}$ This is how the research project on the sources of growth in the Brazilian economy had come to be called in Ford Foundation documents.

${ }^{58}$ Blitzer (1973).

${ }^{59}$ Lopes (1972).

${ }^{60}$ Baer (1973b).
} 
also suggest that no further grants be made to Vargas until structural changes are made which are necessary to turn the institution once again into a respectable research center ${ }^{61}$ (Baer 1973)

On his final evaluative report on IBRE's grant, Donald Blitzer echoed Baer's judgment: “The grant file makes depressing reading - depressing enough to dishearten anybody who would seek the redeeming features, spin-off effects, and long term benefits that the Foundation expects even the most abysmal grants to have" ${ }^{62}$. He also pondered that, in retrospect, the separation between research (IBRE) and graduate training (EPGE) at the Vargas Foundation had been "unfortunate". Closer links could have led to "more serious dedication towards analytical research", but such symbiosis seemed unlikely now that "Mário Simonsen was determined to keep 'his' training program separate"63.

\section{From the extension program to ANPEC}

With the Vargas Foundation temporarily out of the picture, the responsibility for leading the process of building and strengthening a network of Brazilian centers of academic economics fell on IPE's shoulders. By the early 1970s, however, other institutions had begun to emerge as possible candidates for the post of high-level national centers. Ford Foundation staff commonly regarded the University of Brasília, in particular, as the heir apparent to IBRE. On the background report to a grant proposal to UnB, after noting the disappointing performance of the FGV, Gregory Treverton stated that "the University of Brasília is an increasingly attractive alternative to the Vargas Foundation" ${ }^{64}$. Due to its more flexible institutional structure, UnB had even been able to recruit many of the brightest FGV students who had gone abroad for advanced graduate training ${ }^{65}$. Baer and Nicholson concurred with Treverton's assessment: "The likelihood is great that the group [of UnB economists] can perform a number of the analytical and critical functions which the economists at the Vargas Foundation have performed" 66 .

Another prominent center at the time was CEDEPLAR, described by Baer in 1974 as "one of Latin America's leading institutions in regional economics", which had "experienced impressive growth in the quantity and quality of its staff" and "developed a degree of efficiency [in research] which is unique to Brazil" 67 . In this long background report on the current state of Brazilian economics, Baer argued that further FF support should fall under three main headings: 1) terminal, consolidating grants to the three "more advanced centers" - IPE, Brasília, and CEDEPLAR; 2) continuing support to centers whose structure was "still fragile" - CAEN, PIMES, NAEA, and IEPE; and 3) support for the National Association of Graduate Centers, with the purpose of fostering "inter-center cooperation" ${ }^{6}$. This structured, layered type of assistance reflected the general FF strategy for Brazilian economics that had been developing over the course of recent years - and which had the IPE extension program as one of its pillars.

By the end of the 1960s, as the new centers reached greater institutional stability and cooperation among them increased, meetings of representatives began to be periodically held in order to discuss matters of common interest. The third of these meetings took place on January 1970, and its records indicate great concern with issues of domestic exchange and mobility. IPE's leading role was taken for granted, but other centers were also expected to participate more actively in the extension program. One particular goal was to offer "improvement" courses for lecturers in faculties of economics across the country, geared towards the new curricular requirements for undergraduate programs that would soon be approved. It was suggested, however, that these courses should be gradually "regionalized" - in a first moment, CAEN would offer courses in Fortaleza, whereas CEDEPLAR would help with courses in São Paulo. Similar concerns underlay the promotion of short-term high-level courses - a national "pool" of professors being

\footnotetext{
${ }^{61}$ Baer (1973b).

${ }^{62}$ Blitzer (1973).

${ }^{63}$ Blitzer (1973).

64 Treverton (1971).

65 Baer (1971b).

${ }^{66}$ Nicholson (1971).

${ }^{67}$ Baer (1974).

${ }^{68}$ Baer (1974).
} 
created for that purpose - and graduate seminars on special topics - these would be organized locally by each center, but foreign visitors should be shared with other centers whenever possible ${ }^{69}$.

Shortly thereafter, discussions began to address the perspective of a Ford Foundation grant that would help the emerging National Association to reach a more formal status. In a letter written to Baer on May 1970, Nicholson reported on a recent encounter that he and Carmichael had with Colasuonno, in order to go over the details of a grant proposal to the association. Most of the budgeted items were very similar to those found on grants to individual centers: "re-entry funds" for graduates returning from abroad, fellowships for foreign visiting professors, funds for collaborative research efforts, and support for Ph.D. students at the thesis-writing stage ${ }^{70}$. The rationale here was simply that the association would become responsible for allocating these resources among the different centers, according to its first-hand knowledge of their current conditions. In Colasuonno's view, collaborative research was an especially important instrument for solidifying a stratified, coherent interaction between first- and second-tier centers: "[...] coordinated research will demonstrate the capacity of the 'secondary' centers to do research and preserve the delicate balance between the principal and secondary centers" "71. Two items in the proposal, however, represented departures from past practice: post-doctoral fellowships for Brazilian professors in foreign universities, and financial support for national conferences in economics.

Although IPE, through Colasuonno, was clearly the lead player in this first round of negotiations, other centers were also a part of the process. The 1970 grant proposal was the result of a joint effort by Colasuonno, Kerstenetzky, and Paulo Haddad - the latter representing CEDEPLAR. The grant was approved on October 1970, and on the following January Baer already reported on the plans for a National Program of Interchange in Economics. The document attests to Kerstenetzky's imminent departure:

Since Isaac is so busy, Miguel and Paulo will suggest to him that [Hamilton] Tolosa act as a stand-in for him in more routine planning matters. Although I think that this is a good idea, I suggested to Miguel that he deal carefully with Isaac in this matter ${ }^{72}$

The initial concrete measures to be undertaken by the association were stated in a circular letter to all members and other interested parties. The introductory paragraph stated the associations' goals and challenges, while also making it clear how IPE should play a leading role at this stage:

The Brazilian Association of Centers for Training and Research in Economics, through the Institute of Economic Research at the University of São Paulo, has been promoting growing interchange among Brazilian institutions dedicated to graduate training and research in economics. The association's basic goals are reinforcing the economics profession in Brazil, consolidating the organization of a few centers of training and research in economics, increasing efficiency in the allocation of resources through the promotion of complementarity among different centers, developing specialists in fields where the country has chronic shortage, and promoting interaction among Brazilian and foreign institutions ${ }^{73}$

The letter then proceeded to stress the fundamental role played by the Ford Foundation in fostering the development of members of the association, and stated that the recent FF grant to the latter aimed at "reinforcing activities with a multi-institutional scope". After describing the several modes of support available under the grant, the letter concluded establishing a clear connection between IPE's current leadership and its acquired experience in similar extension and exchange programs:

The Ford Foundation has chosen the Institute of Economic Research at the University of São Paulo to manage the grant on account of the considerable organizational competence already demonstrated by the center in different experiences in the promotion and control of joint programs involving several research and training institutions ${ }^{74}$

But if Kerstenetzky's involvement in the fledgling association was curtailed due to his commitments at IBGE, a similar development would soon put IPE's leadership in check. After Colasuonno left his duties at the Institute in 1971 to become Planning Secretary, and later Mayor of the city of São

\footnotetext{
${ }^{69}$ Unidentified author (1970).

${ }^{70}$ Nicholson (1970).

${ }^{71}$ Nicholson (1970).

72 Baer (1971a).

${ }^{73}$ Colasuonno, Kerstenetzky \& Haddad (1971).

${ }^{74}$ Colasuonno, Kerstenetzky \& Haddad (1971).
} 
Paulo, both IPE and the association were brought under the direction of Affonso Celso Pastore. The new director, however, found it difficult to reconcile his new responsibilities in both institutions, and the association therefore suffered. In a January 1972 memorandum to Nicholson, Baer already referred to "the Foundation's disappointment about the slow start the Association had been making" "75. A few weeks later, the association held a meeting of its members in which new patterns of leadership became apparent. An executive committee was created with representatives of four member centers - besides Pastore, Kerstenetzky, and Haddad, the committee also included Edmar Bacha, representing UnB. An important issue at the meeting was the development of a proposal for reforming the curricular requirements for undergraduate programs in economics, and the association decided to hold a meeting along the lines of the Itaipava seminar in order to discuss the matter in more depth. Flávio Versiani, from UnB, was put in charge of organizing the new seminar, which should take place at CEDEPLAR ${ }^{76}$.

Another topic broached at the 1972 meeting was the perspective of giving a formal institutional status to the association, although it was then agreed that it was still "too soon" for such a measure. The Ford Foundation, however, was far from satisfied with the concrete results obtained thus far, and so started pushing for structural changes that could put "more life into the grant". Reporting on the first meeting of the new board of directors, Baer stated that association grant was "of an experimental nature", with the purpose of seeing "how a consortium of economic centers would be able to use such funds in a collaborative way". The results, however, had been "a general disappointment to all of us"77. Although several disturbing factors had interfered with the association's activities, Baer believed that the inadequate leadership exercised by Pastore was a fundamental reason for the dismal performance so far. In light of this assessment, the members dedicated themselves, during the last months of 1972, to gestating a proposal for restructuring the association in a more functional way.

The proposal was given concrete expression in the first meeting of the new Council of Representatives, held at CEDEPLAR on February $1973^{78}$. As for internal organization, it was decided that the association would be led by an executive secretary - a post to be occupied on a rotating basis by the different centers. The Council of Representatives, contemplating seats for all members, should meet twice a year in order to deliberate on the course of activities to be implemented by the executive secretary. Regarding the latter point, the council also established important new directives for the kinds of initiatives that should fall within the competence of the association. According to the report, "the Association should be, fundamentally, an organ for fostering interchange among centers dedicated to graduate training in economics" 79 . More specifically, this meant that the association should not sign contracts in the name of its members, and that it should not serve as an instrument for collecting and distributing research and fellowship funds.

Two important tasks attributed to the association helped to give more clearly defined contours to its new envisaged institutional role: the annual meeting of Brazilian economists, and the unified admission exam for graduate programs. The annual meeting was devised as a forum for the presentation and discussion of original research papers, thus fostering academic interaction among Brazilian economists. The admission exam, on the other hand, had its roots on similar initiatives developed by FGV and IPE during the late 1960s, with the double purpose of standardizing requirements for prospective graduate students and leveling conditions of access to the different programs. Under the association's auspices, the unified exam would be jointly elaborated by all member centers, thus providing a general criterion for admission to the graduate programs that could be adopted exclusively, or complemented by other auxiliary instruments of evaluation. From the perspective of the association's larger institutional project, the unified exam was also important because it provided a clear signaling of the subjects and contents that should be

\footnotetext{
75 Baer (1972).

${ }^{76}$ Unidentified author (1972).

77 Baer (1972).

${ }^{78}$ Present at the meeting were Pastore (IPE), Bacha (UnB), Haddad (CEDEPLAR), Thompson Almeida Andrade (CEDEPLAR), Renato Duarte (PIMES), Maurício Filchtiner (IEPE), and José Hamilton Gondim (CAEN). Although invited, EPGE did not send any representatives.

${ }^{79}$ Associação Nacional de Centros de Pós-Graduação em Economia (1973).
} 
covered in undergraduate programs in economics.

Embracing this new direction, and under the leadership of Paulo $\operatorname{Haddad}^{80}$, the new executive secretary, the association finally began to gain momentum. Reporting on the recent meeting of the new Council, Baer stated: "I am very encouraged by the results of this meeting, and it seems that at last the Association is on its way to function as we originally had envisaged" ${ }^{\prime 1}$. Reynold Carlson was present at the first national meeting, held in São Paulo on November 1973, and reported that discussions were "lively and often provocative", and that "the audience was composed overwhelmingly of young people, graduate students or younger professors, who provided spirited discussions from the floor that spilled over into the corridors after the sessions" ${ }^{\prime 2}$. Ten centers were represented at the meeting, eight of which already offered graduate work at the Master's level. In his closing address, Colasuonno stressed "the advantages of having several decentralized centers of research working on a variety of topics which provide an exceptional opportunity for integration on a nationwide basis" ${ }^{83}$. The first ANPEC meeting, in this sense, was evidence that the long-term development strategy followed by the Ford Foundation and its grantees was finally reaching maturity.

\section{Concluding remarks}

In early 1974, the Ford Foundation was engaged in a wide-ranging assessment of its involvement with Brazilian economics. Summarizing the conclusions reached by several members of the staff, Stanley Nicholson stated:

Our review of the economics program has led us to conclude that three of the programs supported by the Foundation have matured to the point that they constitute a firm base for high-level graduate training and research and that a second level of institutions are rapidly developing their capacity to serve regional needs. All of those involved in the review agree that a critical role in linking the institutions at both levels may be played by the newly-formed Association, though it remains fragile and in need of carefully monitored support ${ }^{84}$

Indeed, the state of academic economics in Brazil in the mid-1970s clearly embodied some of the principles that had structured the Ford Foundation's strategy for developing the economics profession in the country. To the extent that it fostered academic interaction and exchange among its members, ANPEC was an integral part of this strategy. Its origins lay in the recognition, during the late 1960s, that successful regionalization necessarily involved coordinated research activities and domestic staff mobility. The IPE extension program was a crucial link in the historical development of the association, which partially explains the prominent role played by the Institute in its early years. On this point, Baer's testimony is revealing:

The role of IPE [...] has been crucial in helping start a National Association. Under the leadership of Miguel Colasuonno, with the support of the Vanderbilt-AID group, an extension program was developed in which IPE professors gave short-term intensive courses at various centers in fields where staff availability was lacking. This extension service gradually developed into a regular short-term staff exchange program among the centers. Collaboration also extended into research [...], the sharing of visiting foreign professors, the distribution of AID scholarships, and library development programs ${ }^{85}$

"The Association", concluded Baer, "grew out of this interchange program". As the new Brazilian centers matured, however, and new sources of funding became available, the institutional role envisaged for ANPEC also changed. Rather than serving as hub for collecting and distributing funds, the association began to focus on two other goals: stimulating academic interaction among Brazilian economists, in particular by way of its annual meeting; and establishing normative standards for graduate and

\footnotetext{
${ }^{80}$ In a 1974 memorandum to Nicholson, Bruce Bushey stressed his confidence on Haddad's leadership, saying that he was "unusually competent at sorting out the conflicting interests which arise - or become apparent - among member centers as they begin to work more closely together" (Bushey 1974).

${ }^{81}$ Baer (1973a).

${ }^{82}$ Carlson (1973).

${ }^{83}$ Carlson (1973).

${ }^{84}$ Nicholson (1974).

${ }^{85}$ Baer (1974).
} 
undergraduate training in economics, mainly through the unified admission exam. Along precisely these lines, it would exert a marked influence over the course of Brazilian economics for decades to come.

\section{REFERENCES}

\section{DOCUMENTS IN THE FORD FOUNDATION ARCHIVES}

ASSOCIAÇÃO NACIONAL DOS CENTROS DE PÓS-GRADUAÇÃO EM ECONOMIA (1973). Relatório da Segunda Reunião do Conselho da Associação Nacional de Centros de Pós-Graduação em Economia, September 27, 1973; PA70-606, reel 5493.

BAER, Werner (1967). Inter-Office Memorandum, Some Further Comments Related to the Getúlio Vargas Foundation Economic Research and Staff Development Program, to Stacey Widdicombe, August 21, 1967; PA67-573, reel 1886.

BAER, Werner (1968). Inter-Office Memorandum, Comments on the 1967 Report of the Instituto de Pesquisas Econômicas, Faculdade de Ciências Econômicas, Universidade de São Paulo, to Peter Bell, January 5, 1968; PA65-007, reel 5335.

BAER, Werner (1969a). Inter-Office Memorandum, Visit to CAEN, to William Carmichael, January 30, 1969; PA64-407, reel 3637.

BAER, Werner (1969b). Inter-Office Memorandum, Visit to the Getúlio Vargas Foundation, Instituto Brasileiro de Economia (IBRE), August 6, 1969, to William Carmichael, August 8, 1969; PA67-573, reel 1886.

BAER, Werner (1970). Inter-Office Memorandum, Visit to IPE, December 23, 1969, to William Carmichael, January 6, 1970; PA65-007, reel 5335.

BAER, Werner (1971a). Inter-Office Memorandum, Programa Nacional de Intercâmbio em Economia, to William Carmichael and Stanley Nicholson, January 25, 1971; PA70-606, reel 5493.

BAER, Werner (1971b). Inter-Office Memorandum, Report on Visit to the Department of Economics, University of Brasilia: Comments and Recommendation on the Department's Request for Ford Foundation Support, to William Carmichael and Stanley Nicholson, June 11, 1971; PA72-379, reel 6573.

BAER, Werner (1972). Inter-Office Memorandum, University of São Paulo: Association of Economics Graduate Center, to Stanley Nicholson, January 18, 1972; PA70-606, reel 5493.

BAER, Werner (1973a). Inter-Office Memorandum, First Meeting of the New "Conselho da Associação Nacional de Centros de Pós-Graduação em Economia”, to Stanley Nicholson, March 8, 1973; PA70-606, reel 5493.

BAER, Werner (1973b). Inter-Office Memorandum, Narrative Report of IBRE/Fundação Getúlio Vargas (65-573) July 17, 1973, to Stanley Nicholson, August 7, 1973; PA67-573, reel 1886.

BAER, Werner (1974). Inter-Office Memorandum, Turn-Around Grants for Brazilian Economics: a background report, to Stanley Nicholson, March 11, 1974; PA72-379, reel 6573.

BELL, David (1969c). Request for Grant Action, Development of a Graduate Economics Program at the Brazilian University, Supplement No. 1, to McGeorge Bundy, September 19, 1969; PA65-007, reel 5335.

BELL, Peter (1968). Inter-Office Memorandum, Modification of Grant 64-407 to the Federal University of Ceará: Center for Improvement of Economists in the Northeast (CAEN), to Harry Wilhelm, March 4, 1968; PA64-407, reel 3637.

BELL, Peter (1969a). Inter-Office Memorandum, Federal University of Pernambuco, Sociology and Economics, to Harry Wilhelm, August 22, 1969; PA70-138, reel 5389. 
BELL, Peter (1969b). Request for Grant Action, Development of Graduate Training and Research in Sociology and Economics, Federal University of Pernambuco, to McGeorge Bundy, December 23, 1969; PA70-138, reel 5389.

BLITZER, Donald (1973). Inter-Office Memorandum, Getúlio Vargas Foundation, Brazilian Institute of Economics (IBRE), Grant No. 67-753, Final Evaluative Report, to Stanley Nicholson, September 20, 1973; PA67-753, reel 1886.

BRAGA, Raimundo, ARAúJO, José, BELL, Peter \& COLASUONNO, Miguel (1968). Convênio de cooperação que entre si fazem a Universidade Federal do Ceará, o Banco do Nordeste do Brasil S.A., a Fundação Ford e o Instituto de Pesquisas Econômicas da Faculdade de Ciências Econômicas $e$ Administrativas da Universidade de São Paulo, 1968-1971, January 27, 1968; PA64-407, reel 3637.

BUSHEY, Bruce (1974). Inter-Office Memorandum, The National Association of Graduate Centers in Economics: Annual Reports, to Stanley Nicholson, March 18, 1974; PA70-606, reel 5493.

CARLSON, Reynold (1973). Inter-Office Memoradum, Trip to Brazil, November 8-13, 1973, to the Economics Review Files, November 21, 1973; PA70-606, reel 5493.

CARMICHAEL, William (1969). Inter-Office Memorandum, Federal University of Pernambuco, Sociology and Economics, to Harry Wilhelm, September 16, 1969; PA70-138, reel 5389.

CARMICHAEL, William (1970). Inter-Office Memorandum, Economics in São Paulo and More Generally in Brazil, to Nita Manitzas, November 18, 1970; PA65-007, reel 5335.

COLASUONNO, Miguel, KERSTENETZKY, Isaac \& HADDAD, Paulo (1971). Carta-Circular da Associação Brasileira de Centros de Ensino e Pesquisa em Economia; PA70-606, reel 5494.

GEORGESCU-ROEGEN, Nicholas (1967). Report on the Visit to Rio de Janeiro and São Paulo, Brazil (February 11-20, 1967); PA65-007, reel 5335.

LOPES, Luiz Simões (1972). Carta para Anibal Villela, October 26, 1972; PA65-573, reel 1886.

MANITZAS, Nita (1969). Inter-Office Memorandum, Request for "A" Status, Federal University of Pernambuco, Economics and Sociology, to Harry Wilhelm, August 28, 1969; PA70-138, reel 5389.

NICHOLSON, Stanley (1970). Letter to Werner Baer, May 15, 1970; PA70-606, reel 5493.

NICHOLSON, Stanley (1971). Inter-Office Memorandum, University of Brasília, Institute of Human Sciences: Request for "A" Status for Proposed Grant, to William Carmichael, July 16, 1971; PA72-379, reel 6573.

NICHOLSON, Stanley (1974). Inter-Office Memorandum, Review of Foundation Activities in Brazil in Economics, to William Carmichael, March 12, 1974; PA65-007, reel 5335.

SILVERT, Kalman (1969a). Inter-Office Memorandum, Request for “A” Status, Federal University of Pernambuco, Economics and Sociology, to Harry Wilhelm, September 3, 1969; PA70-138, reel 5389.

SILVERT, Kalman (1969b). Inter-Office Memorandum, Federal University of Pernambuco, Sociology and Economics, to Harry Wilhelm, September 22, 1969; PA70-138, reel 5389.

SILVERT, Kalman (1969c). Inter-Office Memorandum, Federal University of Pernambuco, Development of Graduate Training and Research in Sociology and Economics, to Harry Wilhelm, December 16, 1969; PA70-138, reel 5389.

TREVERTON, Gregory (1971). Inter-Office Memorandum, University of Brasília, Institute of Human Sciences: Background and Recommendation for "A" Status for Grant in Economic and Social Science, to Stanley Nicholson, July 16, 1971; PA72-379, reel 6573.

UNIDENTIFIED AUTHOR (1964). Request for Grant Action, Strengthening of Economics Teaching and Research in Northeast Brazil, June 22, 1964; PA64-407, reel 3637. 
UNIDENTIFIED AUTHOR (1970). III Reunião dos Administradores dos Programas de Pós-Graduação e Mestrado em Economia: Resumo das Resoluções Adotadas na Sessão Vespertina do dia 30.1.70, sobre Programas de Intercâmbio; PA70-606, reel 5493.

UNIDENTIFIED AUTHOR (1972). Reunião da Associação de Centros de Pós-Graduação em Economia, February 2, 1972; PA70-606, reel 5493.

WIDDICOMBE, Stacey (1966). Inter-Office Memorandum, University of São Paulo, Graduate Economics Grant, to Reynold Carlson, June 23, 1966; PA65-007, reel 5335.

WIDDICOMBE, Stacey (1967). Inter-Office Memorandum, Getulio Vargas Foundation, Economic Research and Staff Development, to Harry Wilhelm, August 26, 1967; PA67-573, reel 1886.

WILHELM, Harry (1969). Inter-Office Memorandum, Federal University of Pernambuco, Sociology and Economics, to William Carmichael, September 8, 1969; PA70-138, reel 5389.

\section{SECONDARY SOURCES}

ALVES, Márcio M. (1968). Beabá dos MEC-USAID. Rio de Janeiro: Gernasa.

ARAPIRACA, José O. (1979). A USAID e a Educação Brasileira: um estudo a partir e uma abordagem crítica da teoria do capital Humano. (Dissertation, Master's in Education), Fundação Getúlio Vargas Rio de Janeiro.

BACHA, Edmar L. (1996). “Interview”, in: Biderman, Cozac \& Rego (1996), pp. 231-249.

BAER, Werner (1997). Communication at the Roundtable "Seminário da USP - 50 anos de Ciência Econômica no Brasil”, in: Loureiro (1997a), pp. 229-313.

BELLUZZO (1996). “Interview”, in: Biderman, Cozac \& Rego (1996), pp. 251-283.

BIDERMAN, Ciro, Luiz Felipe COZAC \& José Márcio REGO (1996). Conversas com Economistas Brasileiros, São Paulo: Ed. 34.

BIELSCHOWSKY, Ricardo (1988). Pensamento Econômico Brasileiro: o ciclo do desenvolvimentismo, Rio de Janeiro: IPEA/INPES.

CASTRO, Nivalde J. (2001). O Economista: a história da profissão no Brasil, Rio de Janeiro: COFECON/CORECON-RJ/CORECON-SP.

CURY, Carlos R.J. (2005), “Quadragésimo Ano do Parecer CEF No 977/65”, Revista Brasileira de Educação, 30 (3): 7-20.

FAVERO, Maria de Lourdes A. (2006). “A Universidade no Brasil: das origens à reforma Universitária de 1968”, Educar (UFPR), 28: 17-36.

GOODWIN, Craufurd \& NACHT, Michael (1984). Fondness and Frustration: the impact of American higher education on foreign students with special reference to the case of Brazil, New York: Institute of International Education

HADDAD, Paulo R. (1997). Communication at the Roundtable "Seminário da USP - 50 anos de Ciência Econômica no Brasil”, in: Loureiro (1997a), pp. 229-313.

LOUREIRO, Maria Rita (ed.) (1997a). 50 Anos de Ciência Econômica no Brasil: pensamento, instituições, depoimentos, Petrópolis: Vozes.

(1997b). “Introdução", in: Loureiro (1997a), pp. 7-14.

(1997c). "Formação de Quadros para o Governo: as instituições de pesquisa econômica aplicada", in: Loureiro (1997a), pp. 203-225. 
MICELLI, Sérgio (1993). A Aposta numa Comunidade Científica Emergente: a Fundação Ford e os cientistas sociais no Brasil, 1962-1992, in: MICELLI, Sérgio (org.). A Fundação Ford no Brasil, São Paulo: Editora Sumaré, pp. 33-97.

NETTO . Antonio Delfim (1996). “Interview”, in: Biderman, Cozac \& Rego (1996), pp. 89-125.

TAVARES, Maria da Conceição (1996). “Interview”, in: Biderman, Cozac \& Rego (1996), pp. 127-151. 